\title{
The Gender Gap Among EduTubers and the Factors Significantly Influencing It
}

\author{
Daniel Pattier (1) \\ Department of Educational Studies, Complutense University of Madrid, Spain
}

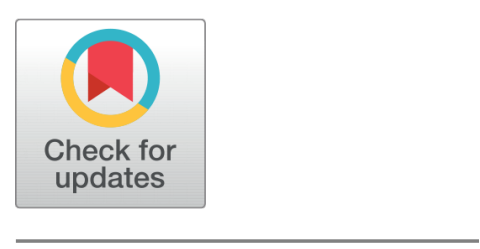

Received 2021-03-02

Revised 2021-03-11

Accepted 2021-04-15

Published 2021-07-15

Corresponding Author

Daniel Pattier,

dpattier@ucm.es

Facultad de Educación (Universidad Complutense de Madrid), Calle Rector Royo

Villanova s/n, 28040, Madrid, Spain

DOI https://doi.org/10.7821/ naer.2021.7.732

Pages: 313-329

Funding: Ministry of Science and Innovation, Spain (Award: PID2019-104566RAIO0/AEI/10.13039/501100011033)

Distributed under

Creative Commons CC BY 4.0

Copyright: (C) The Author(s)

\section{ABSTRACT}

An increased use of YouTube in education has resulted in the emergence of a large number of audiovisual educational content creators known as EduTubers. Our research considers gender as a relevant variable within this group by analysing the 204 most successful channels in Spain so as to identify the existence of models and reference points throughout the area of informal education. The study methodology is based on a qualitative analysis instrument that provides descriptive statistics and contingency tables. The results provide original evidence on the topic. We reflect on the possible existence of a gender gap among EduTubers, concluding that there is actually one. After identifying the significant factors regarding to this inequality, they were grouped together into four categories: media exposure level; women's participation in the educational stages that are most in demand on YouTube; elements and factors determining the success of videos; and time spent on the channel as a content creator. A suggestion is made of possible steps to reduce this gender gap through emotional support and training aimed at women who wish to become EduTubers, as well as via social change that facilitates the presence of women as influential figures in informal education.

Keywords INFORMAL LEARNING, EDUTUBERS, GENDER, EDUCATIONAL VIDEO, YOUTUBE

\section{INTRODUCTION}

\subsection{EduTubers, Educational Influencers on YouTube}

In recent decades, the use of information technology has become commonplace in almost all areas of society. Many fields have been transformed or at least affected by a new digital format that pervades our everyday life. Within this framework, groups and individuals have appeared during the last few years that can now influence millions of people by using social media and digital platforms. The models available on platforms such as YouTube, Instagram, Twitter or Tik-Tok cause a major impact on contemporary society, as shown by the number of views and followers of this multimedia content.

\section{OPEN ACCESS}


EduTubers are especially worth noting special prominence in the field of education. Their audiovisual educational content creations are consumed by viewers both in formal education (Walsh, O'Brien, \& Slattery, 2019), where it can serve as a complement to ordinary classes (Moreira, Santana, \& Bengoechea, 2019), and in informal education (Rodríguez, 2020; Vizcaíno-Verdú, Contreras-Pulido, \& Guzmán-Franco, 2019), where users have the chance to access this content during their free time not only to learn but also to train and instruct themselves on a wide variety of knowledge areas. Note deserves to be highlighted that, during the COVID-19 pandemic, which led to the closure of schools and other educational centres all over the world, education professionals and families have extensively resorted used audiovisual resources to reduce the negative impact derived from the disruption of students' teaching-learning processes. As a result, the OECD has checked that this type of implementation, directed at the broad general audience, has become a genuinely successful practice during this difficult period (Encinas-Martín, 2020). Because of this, creators of educational content on YouTube have increased their international impact even to a greater extent, if that is possible, in terms of numbers of views and subscribers.

Consequently, these groups of educational youtubers have managed to make a place for themselves as an influential factor in current education; hence the importance of researching on this reality as a potential way to identify a number of guidelines for success that can be subsequently applied to formal education.

\subsection{The Gender Gap in the Field of Education and Communication}

Owing to the great influence EduTubers have on users of all ages and socio-economic levels, a real need exists to study the gender profile of this emerging group. Accordingly, it will be possible to establish whether there is a gender gap or not among these highly influential educators as well as to attempt to elucidate the factors underlying this issue. That will allow us to suggest guidelines and projects meant to focused on eliminating any potential discrimination or stereotyping that might happen as a matter of course across this group.

Many studies have suggested that there is still a long way to go to reduce gender gaps in current society (OECD, 2017). In the educational field, special attention needs to be paid to inequalities in different areas and aspects, such as: educational learning outcomes (Borgonovi, Ferrara, \& Maghnouj, 2018); future science career plans (Sikora, 2019); awareness of sustainability (Olsson \& Gericke, 2017); literacy and numeracy (Borgonovi, Choi, \& Paccagnella, 2018); the STEM field (Hussénius, 2020; Reinking \& Martin, 2018; Witherspoon \& Schunn, 2020); time spent on assignments (Gershenson \& Holt, 2015); university spaces (Lever, 2020); reading competence (Torppa, Eklund, Sulkunen, Niemi, \& Ahonen, 2018); primary education teachers (Mistry \& Sood, 2016); academics in higher education (Baker, 2016); and students' self-assessment (Liu, 2018).

Some factors that stand out as having the strongest effect on the gender gap in education are: the influence of friends and the social environment (Raabe, Boda, \& Stadtfeld, 2019); how questions are structured in exams) (Dawkins, Hedgeland, \& Jordan, 2017; Reardon, Kalogrides, Fahle, Podolsky, \& Zárate, 2018); family economic disadvantages (King- 
don, Serbin, \& Stack, 2017); early experiences in particular areas of knowledge (Cheryan, Ziegler, Montoya, \& Jiang, 2017); participation and autonomy (Lietaert, Roorda, Laevers, Verschueren, \& Fraine, 2015); personality and motivation (Wucherer \& Reiterer, 2018); and the level of development of the country (Nicolás \& Rubio, 2016).

As for the field of communication, and more specifically content creators on YouTube, a number of research works attest the existence of a gender gap among successful youtubers, among whom women are a minority (Regueira, Alonso-Ferreiro, \& Da-Vila, 2020). In addition, several studies identify youtubers as reference points for various reasons: they are entertaining and stand close to a digital culture shared with adolescents (Aran-Ramspott, Fedele, \& Tarragó, 2018); they can transfer personal identification aspects to users' life plans (Moreno \& Castañeda, 2019; Pérez-Torres, Pastor-Ruiz, \& Abarrou-Ben-Boubaker, 2018); they can offer models and generate trends and influences with regard to a dominant social mindset (Phelps-Ward \& Laura, 2016), and they are immersed in a virtual space characterised by vulnerability when it comes to media exposure (Montes-Vozmediano, GarcíaJiménez, \& Menor-Sendra, 2018).

Concerning the analysis of educational channels and videos on YouTube, we have found literature that demonstrates the convenience of considering Edutubers' skills, capabilities and attitudes in greater depth (López, Maza-Córdoba, \& Tusa, 2020), examining the statistical data provided by YouTube (Saurabh \& Gautam, 2019) and proposing rubrics to study and assess videos (Neumann \& Herodotou, 2020), together with publications that offer guidelines for the production of videos depending on competences and didactic content (Rodgers et al., 2020) and reflect on the appropriateness of using educational videos on YouTube (Burgos, Beltrán-Pellicer, \& Godino, 2020).

In addition, some studies have shown that a platform like YouTube can become a hub to work on reducing stereotypes in education (Díaz-Fernández \& del Real-Castrillo, 2018) or encouraging digital practices aimed at preventing gender-based violence (Morales, AranRamspott, \& Fedele, 2020). However, no research works have thoroughly dealt with a potential gender gap among EduTubers as a group so far, a lack that this work sets out to address.

\section{METHOD}

\subsection{Research Questions}

Our inquiry revolves around (answering) two questions: Does a gender gap exist among current EduTubers?; and, if that is the case, what factors are significantly influence the status of this gap? Exhaustive analysis of successful educational channels on YouTube will enable us to answer these questions, thus additionally increasing our knowledge of this new phenomenon that affects the field of education internationally. Identifying factors that strongly impact on inequality throughout these groups of educators will make it possible to suggest actions oriented to providing support, training or funding that can help EduTubers eliminate the potential gender gap, which has only recently emerged in the media accordingly allowing us to break with the existing stereotypes and to provide society with models that will undoubtedly have a positive influence on socio-educational contexts. 


\subsection{Sample}

The absence of official lists of EduTubers made us fully aware about the need to find a sufficiently broad sample through which relevant data on the subject could be provided. With that aim, we prepared a list of educational channels on YouTube over two years by systematically searching on YouTube itself, as well as on web pages, blogs and social media. This list was filtered between May and June 2020 considering a taxonomy of predefined categories (Rey, 2007) that comprised the following selection guidelines: country (Spain); channel ownership (individual content creators, not channels run by businesses, associations or institutions); purpose (educational, and not just entertainment-oriented, cooking, crafts, sports...); number of subscribers (a minimum of YouTube Opal level, that is 1,000 subscribers); and number of views (at least 300,000). This resulted in a total sample of 204 successful educational YouTube channels.

\subsection{Instrument}

An instrument comprising 40 items and 7 categories was designed to collect and subsequently analyse the data, the reference model used for its consolidation being a combination of Multimodal Discourse Analysis and Data Mining. The design relied on the contributions of literature about rubrics to analyse the quality of educational videos on YouTube (Neumann \& Herodotou, 2020) as well as other instruments intended to examine audiovisual content in education (Salcedo, Rodriguez, \& Pulido, 2018). Finally, attention was paid to the literature dealing with the different categories of the instrument with the aim of adding some items that we consider to be important for the specific case of educational channels on YouTube. The list of categories was therefore finally configured as follows: dependent variables (Amarasekara \& Grant, 2019; Espino, Suárez, \& GonzálezHenríquez, 2020); statistics provided by the YouTube channel (Cheng, Mehrdad, Ma, Zhang, \& Liu, 2014; Saurabh \& Gautam, 2019); audiovisual structure (Ambrose, Bridges, Dipietro, Lovett, \& Norman, 2010; Arya, Christ, \& Chiu, 2016; Darby \& Lang, 2019; Sahayu \& Friyanto, 2019; Salcedo et al., 2018); the audiovisual material recording and editing process (Aguaded-Gómez \& Medina-Salguero, 2015; Maraza-Quispe, Alejandro-Oviedo, Fernández-Gambarini, Cisneros-Chavez, \& Choquehuanca-Quispe, 2020); the EduTuber's personal brand (Rego-Rey \& Romero-Rodríguez, 2016; Salcedo et al., 2018); channel functionalities offered by the platform (Chen, 2020; Fernández, 2014; Ramírez-Ochoa, 2016; Wilson \& Wu, 2020); and presence on other social networks (Closson \& Bond, 2019; Willet, 2019).

As a result, the instrument's items covered the following aspects of analysis: (1) gender; (2) educational stage; (3) area of knowledge; (4) subscribers; (5) views; (6) date of creation of the channel; (7) date on which videos started being uploaded to the channel; (8) number of videos on the channel; (9) average video uploading volume; (10) average video length; (11) types of videos; (12) language; (13) engagement; (14) presentation of video objectives; (15) relationship with earlier or later videos on the channel; (16) summary or final synthesis of the video; (17) curricular structuring; (18) type of shot used; (19) angle used; (20) number of individuals appearing in the videos; (21) superimposing of images or videos; (22) 
dynamic editing effects; (23) type of language; (24) use of swearwords; (25) use of humour; (26) name with which the EduTuber addresses the audience; (27) channel name type; (28) characteristic clothing; (29) number of EduTubers on the channel; (30) start panel; (31) active comments; (32) links to other channels; (33) playlists; (34) community; (35) shop; (36) channel heading; (37) Patreon or sponsorship; (38) Twitter; (39) Instagram; (40) Facebook.

\subsection{Validation}

Because of its qualitative nature, the analysis instrument was subjected to expert evaluation by five experts, including researchers and university professors, teachers specialised in the use of new technologies in education, professionals from communication sciences and highly-regarded EduTubers in the field of education. The internal consistency of the instrument was demonstrated/proved by an Aiken V coefficient close to 1 for all its items.

\subsection{Procedure}

We used the FREQUENCIES procedure in the SPSS 25.0 program for data analysis, taking into account descriptive statistics and the CROSSTABS procedure examine contingency tables.

The collection and subsequent analysis of data formed part of a process that guaranteed professional ethics at all times.

\subsection{Sample Characteristics}

The sample was characterised by the creation of audiovisual content aimed at the following educational stages: Preschool (5.4\%); Primary Education (13.2\%); Secondary Education (25.5\%); Professional Training (1.5\%); University (3.9\%); and Undefined (50.5\%). Likewise, channels can be distributed by areas of knowledge as follows: $20.1 \%$ sciences; $19.6 \%$ channels without a clear focus on a particular branch of knowledge; $19.1 \%$ art and culture; $14.2 \%$ mathematics; $11.3 \%$ social sciences; $8.8 \%$ humanities; $4.9 \%$ educational technology; and $2 \%$ physical education.

\section{RESULTS}

Seeking to answer our research questions about whether a gender gap currently exists among EduTubers as a group and about which significant factors determine the differences between the men and women who create educational content on YouTube, we analysed the data collected during our research obtaining the results explained below:

\subsection{Results Regarding the Gender Gap}

Firstly, the number of male EduTubers (76\%) is significantly higher than that of females (24\%). Figure 1 shows the percentage of EduTubers who started uploading videos to YouTube over time by gender. 


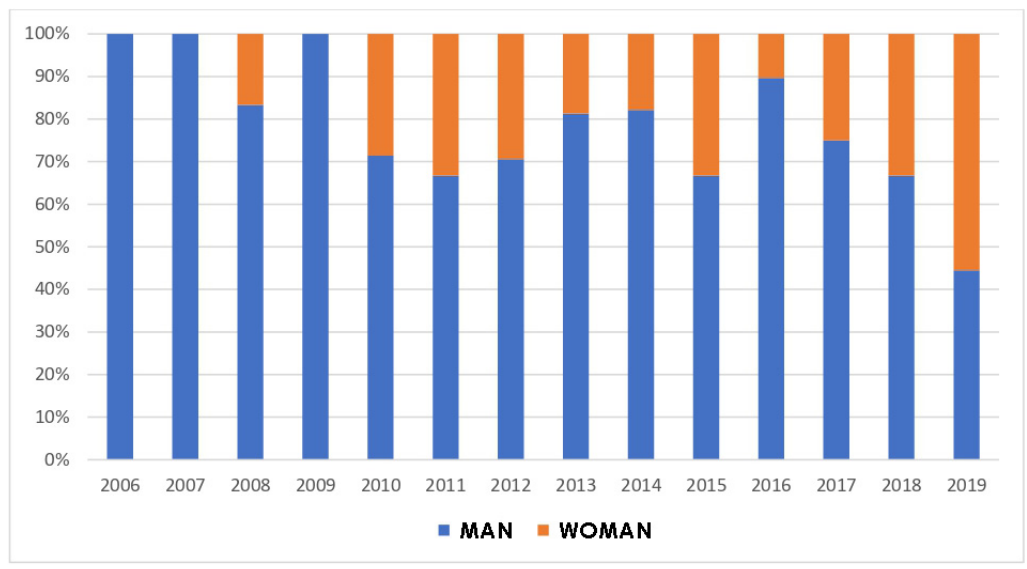

Figure 1 Percentage of EduTubers who started uploading videos to YouTube over time by gender

Furthermore, Table 1 shows the results in relation to the area of knowledge covered on the YouTube channel according to each EduTuber's gender:

\begin{tabular}{lll}
\hline \multicolumn{2}{l}{$\begin{array}{l}\text { Table } 1 \text { Percentage of male and female EduTubers by YouTube } \\
\text { channel area of knowledge }\end{array}$} \\
Area of knowledge & Male EduTubers & Female EduTubers \\
\hline Sciences & $80.5 \%$ & $19.5 \%$ \\
Social Sciences & $87 \%$ & $13 \%$ \\
Mathematics & $82.8 \%$ & $17.2 \%$ \\
Humanities & $61.1 \%$ & $38.9 \%$ \\
Physical Education & $75 \%$ & $25 \%$ \\
Technology & $90 \%$ & $10 \%$ \\
Art and Culture & $64.1 \%$ & $35.9 \%$ \\
Other/Undefined & $75 \%$ & $25 \%$ \\
\hline
\end{tabular}

Source: Own Elaboration

\subsection{Significant factors by gender}

Significant differences $(p<.01)$ also appeared when comparing the variables related to gender and educational stage. As can be seen in Table 2, a major disparity exists in the proportion of male and female EduTubers depending on the educational level in which they are active. 
Table 2 Distribution of male and female EduTubers by the stage at which the channel is aimed

\begin{tabular}{lll} 
Stage & Male EduTubers & Female EduTubers \\
\hline Early Years & $0.6 \%$ & $20.4 \%$ \\
Primary Education & $14.8 \%$ & $8.2 \%$ \\
Secondary Education & $27.7 \%$ & $18.4 \%$ \\
Professional Training & $1.3 \%$ & $2 \%$ \\
University & $2.6 \%$ & $8.2 \%$ \\
Undefined & $52.9 \%$ & $42.9 \%$ \\
\hline
\end{tabular}

Source: Own Elaboration

The category corresponding to the statistics provided by the YouTube channel revealed a significant difference $(p=.016)$ in the item related to the number of videos uploaded to the channel. The results are collected in Table 3:

Table 3 Number of videos on the respective YouTube channels by EduTubers' gender

\begin{tabular}{lll} 
Number of videos on the YouTube channel & Male EduTubers & Female EduTubers \\
\hline $1-10$ videos & $0.6 \%$ & $0 \%$ \\
$11-50$ videos & $14.2 \%$ & $24.5 \%$ \\
$51-100$ videos & $14.2 \%$ & $30.6 \%$ \\
$101-1,000$ videos & $67.8 \%$ & $42.9 \%$ \\
More than 1,000 videos & $3.2 \%$ & $2 \%$ \\
\hline
\end{tabular}

Source: Own Elaboration

By contrast, there is no evidence of gender inequality in the audiovisual structure category. In other words, men and women structure the audiovisual resources they upload to YouTube in the same way.

The process of recording and editing videos section revealed significant differences $(p$ $<.05)$ concerning the shot used while filming, with women tending to use close-ups to a lesser extent and choosing long shots more often than men. A dissimilarity $(p<.01)$ likewise becomes apparent with regard to the utilisation of images or videos through the superimposition used during the video editing process, with a tendency for women to use this type of editing option less frequently in their videos.

We observed visible dissimilarities in the category associated with EduTuber's personality, both on their channels and in their videos. For example, differences appeared $(p<.05)$ concerning the type of language used in the videos, those created by women being characterised by a remarkably greater presence of childish language. Similarly, a disparity $(p<.05)$ arose in the use of humour, since women tend to resort to humour in their videos less often than men. Furthermore, although the data is not statistically significant, our findings show that women use a particular name to address the audience less frequently than men. In contrast, women utilise their own personal names or surnames as a title for their channels to a greater extent than men. 
As for the channel functionalities that YouTube offers content creators, a difference becomes clear $(p<.01)$ in the decision to share a channel with more than one EduTuber: women usually do so more frequently than men. In addition, men make a notably greater use not only of the Community function but also of the option to enable links to other YouTube channels $(p<.05)$.

Finally, no significant differences by EduTubers' gender were found in the category corresponding to the presence of the channel on other social networks (Twitter, Instagram and Facebook).

Accordingly, as Table 4 shows, the results identify factors and areas where significant differences exist in relation to some items within the categories analysed.

Table 4 Significant differences in the categories analysed by gender

\begin{tabular}{lll} 
Category & Significant difference & Items \\
\hline Dependent variables & Yes & Gender and educational stage \\
Statistics provided by the YouTube channel & Yes & Number of videos uploaded to the channel \\
Audiovisual structure & Yes & No \\
Recording and editing process & & $\begin{array}{l}\text { Type of shot (filming) and superimposing of images or } \\
\text { videos (editing) }\end{array}$ \\
EduTuber's personality & Yes & Type of language and use of humour \\
Channel functionalities & Yes & Number of EduTubers on the channel, Community \\
& & function and connection with other YouTube channels \\
Presence on other social networks & No & No \\
\hline
\end{tabular}

Source: Own Elaboration

\section{DISCUSSION}

Analysing the data that we obtained allows us to answer our research questions. Firstly, we can state that a gender gap currently exists among creators of educational content on YouTube. Taking into account the fact that a large proportion of current EduTubers come from the professional sphere of teaching and also that women account for $66.6 \%$ of the people working in this area (MEFP, 2020), we would have expected to find similar figures in our research. However, the results show that 3 out of 4 EduTubers are males, which reflects a striking shortfall when it comes to the presence of women in educational content creation on YouTube. This statement is in line with the outcome of other research works into gender among successful youtubers from other areas (Regueira et al., 2020).

Nonetheless, as Figure 1 shows, this gap has gradually been shrinking since 2017 when the percentage of female EduTubers compared with male ones started to increase. Even so, the current overview of EduTubers on YouTube, as stated above, reveals a major absence of women within such an influential group in contemporary education.

Taking this into consideration, we should try to clarify the differences between men and women in order to understand the complex reality that we are facing (Menéndez, 2019) and to be able to identify steps to continue reducing this gap and accelerating this trend for women to take the step towards becoming educational references through platforms such 
as YouTube.

Therefore, and answering our second research question about factors that have a significant impact on the gender gap among EduTubers, significant differences between male and female EduTubers are become obvious regarding the following categories collected in Table 4: dependent variables; statistics provided by the YouTube channel; recording and editing process; the EduTuber's personality; and channel functionalities. By contrast, the audiovisual structure categories (Broeckelman-Post, Hawkins, Murphy, Otusanya, \& Kueppers, 2020) and presence on other social networks (Closson \& Bond, 2019; Willet, 2019) show no outstanding differences between men and women.

The awareness about the importance of highlighting the reasons for this contrast in the items analysed where significant differences exist between male and female EduTubers led us to establish four broad areas which can be identified as possible origins of the current gender gap: YouTube content creators' media exposure level; the smaller presence of female EduTubers in the educational stages that are most in demand on YouTube; the use of elements and factors of success in audiovisual resources; and the time spent on the channel by the EduTuber.

Firstly, several items revealed outstanding differences between men and women which can be grouped together around a common factor: the media exposure associated with from being an EduTuber (Montes-Vozmediano et al., 2018). Our data support the claim that women tend to display themselves to a lesser extent both quantitatively (female EduTubers' channels usually provide fewer videos; they choose to team up with other EduTubers to create channels more often than men; and they resort less frequently to use the community function of channels which permits an interrelation with the audience) and qualitatively (women clearly show a preference for long shots as opposed to close-ups in their videos, and they do not use links to other YouTube channels that generate a network between the EduTubers themselves as often as men). These data match other results obtained in previous research studies dedicated on digital security according to gender within the educational field (Grande-De-Prado, Cañón-Rodríguez, \& García-Martín, 2020). These aspects are closely related not only to women's social participation on the internet and their autonomy (Lietaert et al., 2015) but also to the proven presence of offensive and sexist comments towards female youtubers (Amarasekara \& Grant, 2019).

Secondly, we have attested the existence of inequalities relating to the small number of female EduTubers in the educational stages that are most in demand on YouTube. As evidenced by the results of this study, 9 out of 10 educational channels that we found on YouTube correspond to the primary or secondary stages of education or do not belong to any defined educational stage. These particular stages record the lowest proportion of female EduTubers (Table 2), which in turn promotes a significant gender gap regarding the number of successful YouTube educational channels directed by women (Cheng et al., 2014; Saurabh \& Gautam, 2019).

It is important to note that, with regard to the knowledge area to which the channel belongs, and even if no significant differences appear, the possibility exists to estimate the areas of knowledge more prone to make a greater difference when it comes to the presence 
of female EduTubers. Therefore,Table 2 shows that a greater difference becomes apparent in Sciences (Reinking \& Martin, 2018; Witherspoon \& Schunn, 2020), Social Sciences, Mathematics (Yong, 2017) and Technology, where the number of women is proportionally lower. Therefore, the various programmes or projects that promote women's empowerment according to specific areas of knowledge should reinforce these disciplinary categories as a way to prevent this gendered difference from becoming accentuated over the coming years and so that it can be reversed by pursuing true equality in this respect.

Thirdly, the results of our research point towards a possible origin of the gender gap among EduTubers deriving from whether they use particular elements of audiovisual content on YouTube and take advantage of certain success factors in the process (López et al., 2020; Pattier, 2021; Srinivasacharlu, 2020), especially in categories relating to the process of recording and editing videos, which in turn has to do with Edutuber's personality (RegoRey \& Romero-Rodríguez, 2016; Salcedo et al., 2018; Wucherer \& Reiterer, 2018). The data collected show that women edit fewer videos; they tend to use close-ups less frequently; they do not use humour in their audiovisual resources as much as their male counterparts; and they use childish language more often than men. However, the statistics corresponding to the most successful YouTube channels follow an opposite trend in terms of these elements, with YouTubers usually appearing in a fun and friendly way, resorting a youthful or standardised language (Long, Logan, \& Waugh, 2016; Rodgers et al., 2020), trying to reach a broad general audience (Vizcaíno-Verdú, De-Casas-Moreno, \& Contreras-Pulido, 2020) and developing a clear resource editing process so that their audience can spend more time viewing the channel's content. Therefore, the dissimilarity between men and women concerning the creation of videos (Förster \& Happ, 2019) could be one of the factors directly impacting on the recognition and positioning of the channel and, consequently, on the gender ratios between successful YouTube educational channels on YouTube.

Fourthly, we note that women usually spend less time recording videos (fewer videos are available on women's channels), editing them (they do not resort to such editing elements as superimposed images or videos so often) and establishing a regular relationship with the audience (they use the Community function to a lesser extent). If women are spending less time than their male counterparts on everything that having an educational channel on YouTube entails, then the likelihood of their channels being as successful as those of men decreases significantly. This dissimilarity in the time men and women spend on their YouTube channels might be closely related to their chances of achieving a good work-life balance or the existence of an unequal housework distribution (Gershenson \& Holt, 2015; Rentzou, 2018) together with the digital gender gap (Pujol \& Montenegro, 2015), as highlighted by previous research works too.

\section{CONCLUSIONS}

The data analysis carried out in this study enabled us to answer our research questions. Firstly, it showed a large gender gap among current EduTubers for the first time in the literature, albeit one that has tended to shrink in recent years. Secondly, we identified the 
factors significantly influencing the reality of this gap that depend on the following analysis categories: dependent variables; the YouTube channel's statistics; the recording and editing process; the EduTuber's personality; and channel functionalities of the channel. As seen in Table 5, these factors can be grouped together around four issues that we have identified as contributing to the gender gap among current EduTubers in this work: media exposure level; women's participation in the educational stages most in demand on YouTube; elements of videos and factors affecting their success; and time spent on the channel as an EduTuber.

Table 5 Categories affecting the gender gap among EduTubers and results on which they are based

\begin{tabular}{|c|c|}
\hline Categories & Results on which they are based \\
\hline \multirow[t]{5}{*}{ Media exposure level } & Female EduTubers create fewer videos \\
\hline & Women tend to join up more often with other EduTubers to create YouTube channels \\
\hline & Female EduTubers use the Community function less frequently \\
\hline & Female EduTubers do not use close-ups so much \\
\hline & Female EduTubers use the 'connecting with other YouTube channels' function less frequently \\
\hline \multirow[t]{2}{*}{$\begin{array}{l}\text { Presence of female EduTubers in the stages } \\
\text { most in demand on YouTube }\end{array}$} & $\begin{array}{l}\text { The educational channels in most-demanded on YouTube belong to the primary education and } \\
\text { secondary education stages or do not have a relate to a specific stage }\end{array}$ \\
\hline & $\begin{array}{l}\text { The presence of female EduTubers is proportionally lower in channels related to primary education, } \\
\text { secondary education and undefined stage }\end{array}$ \\
\hline \multirow{5}{*}{$\begin{array}{l}\text { Elements of videos and factors determining } \\
\text { their success }\end{array}$} & Female EduTubers edit videos less often \\
\hline & Female EduTubers do not use close-ups so much \\
\hline & Female EduTubers use humour to a lesser extent \\
\hline & Female EduTubers use childlike language more frequently \\
\hline & Female EduTuber's videos follow, to a lesser extent, the trends of success in YouTube channels \\
\hline \multirow[t]{3}{*}{ Time spent on the channel } & Female EduTubers spend less time recording videos \\
\hline & Female EduTubers spend less time editing videos \\
\hline & Female EduTubers establish a less frequent relationship with their audience \\
\hline
\end{tabular}

Source: Own Elaboration

Based on the considerations highlighted above, and with the aim of demonstrating the existence of a gender gap in the group of EduTubers and also of suggesting guidelines or ideas drawn from the results of our research that various competent organisations (Pattier \& Rueda, 2021) could take into account to reduce this inequality, below can be found some potential actions worth considering.

Firstly, and bearing in mind the proven greater impact of media exposure on women, as discussed in this work, a recommendation is made to promote projects that focus on improving their self-concept, overcoming stereotypes and encouraging a female entrepreneurial spirit for the purpose of creating an inner security through which the predisposition to become an EduTuber can grow among women. Such actions must focus on women who wish to create educational audiovisual content, establishing a prioritisation of specific efforts depending on the stage (mainly primary and secondary education) and the area of knowledge (especially in Sciences, Social Sciences, Mathematics and Technology). 
In addition, YouTube as a platform needs to significantly improve the option to assess videos by blocking any sexist or offensive comments directed at the content creator or other channel users with a mathematical algorithm, offering better security to handle media exposure on this platform.

Likewise, when it comes to the differences found between men and women regarding the creation and editing of videos, further research should be done into this area, which relates to the area of communication as a whole and to trends in the consumption of audiovisual resources. Such research, alongside evidence-based training, would allow women to take more full advantage of the elements and factors that determine success when creating YouTube's audiovisual resources. In this way, by adapting the video creating and editing process to the demands of the current audience, women could improve their channels' statistics (Cheng et al., 2014; Saurabh \& Gautam, 2019) and thus become reference points among EduTubers as a group (López et al., 2020; Regueira et al., 2020).

Finally, in the light of the results according to which women spend less time than men on their YouTube channels, it seems to us that an urgent need exists to implement actions meant to support an effective work-life balance and encourage a change in society's mindset (Phelps-Ward \& Laura, 2016) so that an equitable housework distribution can be favoured. Governments and businesses still have some way to go on these lines to promote that men and women are really on an equal footing when it comes to the capacity and time that they can devote to other areas of social and professional life, such as the creation of audiovisual content on YouTube.

This will allow us to advance towards a necessary reduction in the gender gap among EduTubers as a group that comprises an unequal establishment of models which are likely to influence personality development (Pérez-Torres et al., 2018; Phelps-Ward \& Laura, 2016), above all of the youngest age groups (Moreno \& Castañeda, 2019), from the area of informal education (Rodríguez, 2020; Vizcaíno-Verdú et al., 2019).

The limitations faced in this study derive from the fact that it only analyses Spanish YouTube educational channels. Studying channels from other countries could be a source of useful data worth considering, since they relate directly to the culture of which they form part. In any case, the results of our research seem to be in line with those obtained in other studies performed internationally and could therefore help confirm the reliability of our statements.

It is important to worth highlighting that we collected the data for this research during the first months of the COVID-19 pandemic, which largely affected the international educational panorama. The closure of educational centres caused a substantial change in the methodology used by education professionals, since they found themselves obliged to create new audiovisual materials for asynchronous use in the teaching-learning process. Therefore, once the pandemic has ended, studying potential changes in trends caused by this international emergency situation will undoubtedly be an area of great interest. 


\section{ACKNOWLEDGEMENTS}

This work was supported by the Spanish Ministry of Science and Innovation under Grant Number PID2019-104566RA-I00/AEI/10.13039/501100011033 through the "\#LobbyingTeachers: Theoretical foundations, political structures and social practices of public-private relations in the field of teachers in Spain" R\&D project.

Funded by: Ministry of Science and Innovation, Spain

Funder Identifier: http://dx.doi.org/10.13039/501100004837

Award: PID2019-104566RA-I00/AEI/10.13039/501100011033

\section{REFERENCES}

Aguaded-Gómez, J. I., \& Medina-Salguero, R. (2015). Criterios de calidad para la valoración y gestión de MOOC. RIED. Revista Iberoamericana de Educación a Distancia, 18(2), 119-143. https://doi.org/10.5944/ried.18.2.13579

Amarasekara, I., \& Grant, W. J. (2019). Exploring the YouTube science communication gender gap: A sentiment analysis. Public Understanding of Science, 28(1), 68-84. https://doi.org/10.1177/ 0963662518786654

Ambrose, S. A., Bridges, M. W., Dipietro, M., Lovett, M. C., \& Norman, M. K. (2010). How Learning Works: Seven Research-based Principles for Smart Teaching. John Wiley \& Sons.

Aran-Ramspott, S., Fedele, M., \& Tarragó, A. (2018). YouTubers' social functions and their influence on pre-adolescence. Comunicar, 26(57), 71-80. https://doi.org/10.3916/c57-2018-07

Arya, P., Christ, T., \& Chiu, M. M. (2016). Video use in teacher education: a survey of teachereducators' practices across disciplines. Journal of Computing in Higher Education, 28(2), 261300. https://doi.org/10.1007/s12528-016-9116-y

Baker, M. (2016). Women Graduates and the Workplace: Continuing Challenges for Academic Women. Studies in Higher Education, 41(5), 887-900. https://doi.org/10.1080/03075079.2016 .1147718

Borgonovi, F., Choi, A., \& Paccagnella, M. (2018). The Gender Gap in Educational Outcomes in Norway. OECD Education Working Papers.

Borgonovi, F., Ferrara, A., \& Maghnouj, S. (2018). The Evolution of Gender Gaps in Numeracy and Literacy between Childhood and Adulthood. OECD Education Working Papers.

Broeckelman-Post, M. A., Hawkins, K. E. H., Murphy, J., Otusanya, A., \& Kueppers, G. (2020). The impact of gender and introductory communication course type on public speaking performance. Communication Teacher, 34, 53-67. https://doi.org/10.1080/17404622.2019.1593478

Burgos, M., Beltrán-Pellicer, P., \& Godino, J. D. (2020). The issue of didactical suitability in mathematics educational videos: Experience of analysis with prospective primary school teachers. Revista Española de Pedagogía, 78(275), 27-50. https://doi.org/10.22550/rep78-1-2020-07

Chen, C. W. Y. (2020). Analyzing Online Comments: A Language-awareness Approach to Cultivating Digital Literacies. Computer Assisted Language Learning, 33(4), 435-454. https://doi.org/ 10.1080/09588221.2019.1569068

Cheng, X., Mehrdad, F., Ma, X., Zhang, C., \& Liu, J. (2014). Understanding the YouTube partners and their data: Measurement and analysis. China Communications, 11, 26-34. https://doi.org/ 10.1109/cc.2014.7019837

Cheryan, S., Ziegler, S. A., Montoya, A. K., \& Jiang, L. (2017). Why are some STEM fields more gender balanced than others? Psychological Bulletin, 143(1), 1-35. https://doi.org/10.1037/ bul0000052 
Closson, L. M., \& Bond, T. A. (2019). Social network site use and university adjustment. Educational Psychology, 39(8), 1027-1046. https://doi.org/10.1080/01443410.2019.1618443

Darby, F., \& Lang, J. M. (2019). Small Teaching Online: Applying Learning Science in Online Classes. John Wiley \& Sons.

Dawkins, H., Hedgeland, H., \& Jordan, S. (2017). Impact of scaffolding and question structure on the gender gap. Physical Review Physics Education Research, 13(2), 1-8. https://doi.org/ 10.1103/physrevphyseducres.13.020117

Díaz-Fernández, A.-M., \& del Real-Castrillo, C. (2018). Spies and security: Assessing the impact of animated videos on intelligence services in school children. Comunicar, 26(56), 81-89. https://doi.org/10.3916/c56-2018-08

Encinas-Martín, M. (2020). Spain: Aprendo en casa (Learn at home), Education continuity stories series. OECD Publishing.

Espino, J. M. S., Suárez, M. D. A., \& González-Henríquez, J. J. (2020). Video for teaching: classroom use, instructor self-production and teachers' preferences in presentation format. Technology, Pedagogy and Education, 29(2), 147-162. https://doi.org/10.1080/1475939x.2020.1726805

Fernández, C. (2014). Prácticas transmedia en la era del prosumidor: hacia una definición de contenido generado por el usuario. Cuadernos de Información y Comunicación, 19, 53-67. https://doi.org/10.5209/rev_ciyc.2014.v19.43903

Förster, M., \& Happ, R. (2019). The relationship among gender, interest in economic topics, media use, and the economic knowledge of students at vocational schools. Citizenship, Social and Economics Education, 18, 143-157. https://doi.org/10.1177/2047173419892209

Gershenson, S., \& Holt, S. B. (2015). Gender Gaps in High School Students' Homework Time. Educational Researcher, 44(8), 432-441. https://doi.org/10.3102/0013189x15616123

Grande-De-Prado, M., Cañón-Rodríguez, R., \& García-Martín, S. (2020). Digital Security, how do teachers in training perceived themselves. IJERI: International Journal of Educational Research and Innovation, 14, 262-275. https://doi.org/10.46661/ijeri.3983

Hussénius, A. (2020). Trouble the gap: gendered inequities in STEM education. Gender and Education, 32(5), 573-576. https://doi.org/10.1080/09540253.2020.1775168

Kingdon, D., Serbin, L. A., \& Stack, D. M. (2017). Understanding the gender gap in school performance among low-income children. International Journal of Behavioral Development, 41(2), 265-274. https://doi.org/10.1177/0165025416631836

Lever, L. V. (2020). University Spaces, Gender and Position of Social Origin: Intersection of Inequalities. Gender and Education, 32(4), 518-536. https://doi.org/10.1080/09540253.2018.1501004

Lietaert, S., Roorda, D., Laevers, F., Verschueren, K., \& Fraine, B. D. (2015). The gender gap in student engagement: The role of teachers' autonomy support, structure, and involvement. British Journal of Educational Psychology, 85(4), 498-518. https://doi.org/10.1111/bjep.12095

Liu, R. (2018). Gender-Math Stereotype, Biased Self-Assessment, and Aspiration in STEM Careers: The Gender Gap among Early Adolescents in China. Comparative Education Review, 62(4), 522-541. https://doi.org/10.1086/699565

Long, T., Logan, J., \& Waugh, M. (2016). Students' Perceptions of the Value of Using Videos as a Pre-class Learning Experience in the Flipped Classroom. TechTrends, 60, 245-252. https:// doi.org/10.1007/s11528-016-0045-4

López, J. L., Maza-Córdoba, J., \& Tusa, F. (2020). Educar en el Contexto Digital: El Reto de Ser Edutuber. Revista Ibérica de Sistemas e Tecnologias de Informação, E25, 188-200. Retrieved from http://www.risti.xyz/issues/ristie25.pdf

Maraza-Quispe, B., Alejandro-Oviedo, O., Fernández-Gambarini, W., Cisneros-Chavez, B., \& Choquehuanca-Quispe, W. (2020). Análisis de YouTube como herramienta de investigación documental en estudiantes de educación superior. Publicaciones: Facultad de Edu- 
cación y Humanidades del Campus de Melilla, 50(2), 133-147. https://doi.org/10.30827/ publicaciones.v50i2.13949

Menéndez, M. I. M. (2019). Can Advertising be Feminist? Ambivalence and Gender Interests in "Femvertising" from a Case Study: Campofrio's "Deliciosa Calma". Revista de Estudios Sociales, 68, 88-100. https://doi.org/10.7440/res68.2019.08

Ministerio de Educación y Formación Profesional. MEFP. (2020). Igualdad en cifras: Aulas por la igualdad. Secretaría General Técnica.

Mistry, M., \& Sood, K. (2016). Busting the Myth of Gender Bias: Views from Men and Women Primary-school Trainees and Teachers. Education 3-13, 44(3), 283-296. https://doi.org/10 $.1080 / 03004279.2014 .922595$

Montes-Vozmediano, M., García-Jiménez, A., \& Menor-Sendra, J. (2018). Teen videos on YouTube: Features and digital vulnerabilities. Comunicar, 26(54), 61-69. https://doi.org/10.3916/c54 -2018-06

Morales, E. V., Aran-Ramspott, S., \& Fedele, M. (2020). Jugando a ser YouTubers: prácticas digitales para la prevención de la violencia de género. ZER - Revista de Estudios de Comunicación, 25, 289-308. https://doi.org/10.1387/zer.21570

Moreira, J. A. M., Santana, C. L., \& Bengoechea, A. G. (2019). Teaching and learning in digital social networks: The Mathgurl case on YouTube. Revista de la SEECI, 50, 107-127. https://doi.org/ 10.15198/seeci.2019.50.107-127

Moreno, K. P., \& Castañeda, S. E. V. (2019). Los YouTubers: espejos influyentes en el proyecto de vida adolescente. Imaginario Social, 2(2). http://www.revista-imaginariosocial.com/index.php/es/ article/view/13

Neumann, M. M., \& Herodotou, C. (2020). Evaluating YouTube videos for young children. Education and Information Technologies, 25, 4459-4475. https://doi.org/10.1007/s10639-020-10183 $-7$

Nicolás, C., \& Rubio, A. (2016). Social enterprise: Gender gap and economic development. European Journal of Management and Business Economics, 25(2), 56-62. https://doi.org/10.1016/ j.redeen.2015.11.001

OECD. (2017). The Pursuit of Gender Equality-An Uphill Battle. OECD publishing.

Olsson, D., \& Gericke, N. (2017). The effect of gender on students' sustainability consciousness: A nationwide Swedish study. The Journal of Environmental Education, 48(5), 357-370. https:// doi.org/10.1080/00958964.2017.1310083

Pattier, D. (2021). Science on Youtube: Successful Edutubers. TECHNO REVIEW. International Technology, Science and Society Review, 10(1), 1-15. https://doi.org/10.37467/gka-revtechno .v10.2696

Pattier, D., \& Rueda, P. O. (2021). Administration and teachers: Evidence-based educational practices. Revista de Educación, 392, 33-58. https://doi.org/10.4438/1988-592X-RE-2021-392 $-478$

Pérez-Torres, V., Pastor-Ruiz, Y., \& Abarrou-Ben-Boubaker, S. (2018). YouTuber videos and the construction of adolescent identity. Comunicar, 26(55), 61-70. https://doi.org/10.3916/c55 -2018-06

Phelps-Ward, R. J., \& Laura, C. T. (2016). Talking back in cyberspace: self-love, hair care, and counter narratives in Black adolescent girls' YouTube vlogs. Gender and Education, 28(6), 807-820. https://doi.org/10.1080/09540253.2016.1221888

Pujol, J., \& Montenegro, M. (2015). Technology and Feminism: A Strange Couple. Revista de Estudios Sociales, 51, 173-185. https://doi.org/10.7440/res51.2015.13

Raabe, I. J., Boda, Z., \& Stadtfeld, C. (2019). The Social Pipeline: How Friend Influence and Peer Exposure Widen the STEM Gender Gap. Sociology of Education, 92(2), 105-123. https:// 
doi.org/10.1177/0038040718824095

Ramírez-Ochoa, M. I. (2016). YouTube's educational possibilities uses. Ra Ximhai, 12(6), 537-546. https://doi.org/10.35197/rx.12.01.e3.2016.34.mr

Reardon, S. F., Kalogrides, D., Fahle, E. M., Podolsky, A., \& Zárate, R. C. (2018). The Relationship Between Test Item Format and Gender Achievement Gaps on Math and ELA Tests in Fourth and Eighth Grades. Educational Researcher, 47(5), 284-294. https://doi.org/10.3102/ 0013189x18762105

Rego-Rey, S., \& Romero-Rodríguez, L. M. (2016). Representación Discursiva y Lenguaje de los Youtubers Españoles: Estudio de Caso de los Gamers más Populares. Index Comunicación, 6(1), 197-224. Retrieved from http://hdl.handle.net/10115/15472

Regueira, U., Alonso-Ferreiro, A., \& Da-Vila, S. (2020). Women on YouTube: Representation and participation through the Web Scraping technique. Comunicar, 28(63), 31-40. https://doi .org/10.3916/c63-2020-03

Reinking, A., \& Martin, B. (2018). The Gender Gap in STEM Fields: Theories, Movements, and Ideas to Engage Girls in STEM. Journal of New Approaches in Educational Research, 7(2), 148-153. https://doi.org/10.7821/naer.2018.7.271

Rentzou, K. (2018). Family support and early childhood education and care in Cyprus: existing policies and challenges. Early Child Development and Care, 188, 571-583. https://doi.org/ 10.1080/03004430.2018.1433172

Rey, F. L. G. (2007). Investigación Cualitativa y Subjetividad. McGraw-Hill.

Rodgers, T. L., Cheema, N., Vasanth, S., Jamshed, A., Alfutimie, A., \& Scully, P. J. (2020). Developing pre-laboratory videos for enhancing student preparedness. European Journal of Engineering Education, 45(2), 292-304. https://doi.org/10.1080/03043797.2019.1593322

Rodríguez, E. R. (2020). Youtube Tutorials as a Non-Formal Learning Strategy for University Students. RIDE Revista Iberoamericana para la Investigación y el Desarrollo Educativo, 11-21. https://doi.org/10.23913/ride.v11i21.797

Sahayu, W., \& Friyanto. (2019). The Effect of YouTube on High School Students' Second Language Acquisition. International Journal of Linguistics, Literature and Translation, 2(6), 38-44. https://doi.org/10.32996/ijllt.2019.2.6.5

Salcedo, E. M. M., Rodriguez, A. P., \& Pulido, P. C. (2018). Propuesta de diseño de instrumento para analizar vídeo-lecciones en MOOC. Alteridad, 14(1), 53-64. https://doi.org/10.17163/ alt.v14n1.2019.04

Saurabh, S., \& Gautam, S. (2019). Modelling and statistical analysis of YouTube's educational videos: A channel Owner's perspective. Computers \& Education, 128, 145-158. https://doi.org/10 .1016/j.compedu.2018.09.003

Sikora, J. (2019). Is it All About Early Occupational Expectations? How the Gender Gap in Two Science Domains Reproduces Itself at Subsequent Stages of Education: Evidence from Longitudinal PISA in Australia. International Journal of Science Education, 41(16), 2347-2368. https://doi.org/10.1080/09500693.2019.1676933

Srinivasacharlu, A. (2020). Using Youtube in Colleges of Education. Shanlax International Journal of Education, 8(2), 21-24. https://doi.org/10.34293/education.v8i2.1736

Torppa, M., Eklund, K., Sulkunen, S., Niemi, P., \& Ahonen, T. (2018). Why do boys and girls perform differently on PISA Reading in Finland? The effects of reading fluency, achievement behaviour, leisure reading and homework activity. Journal of Research in Reading, 41(1), 122139. https://doi.org/10.1111/1467-9817.12103

Vizcaíno-Verdú, A., Contreras-Pulido, P., \& Guzmán-Franco, M.-D. (2019). Reading and informal learning trends on YouTube: The booktuber. Comunicar, 27, 95-104. https://doi.org/10.3916/ c59-2019-09 
Vizcaíno-Verdú, A., De-Casas-Moreno, P., \& Contreras-Pulido, P. (2020). Scientific Dissemination on YouTube and its Reliability for University Professors. Educación XX1, 23(2), 283-306. https://doi.org/10.5944/educxx1.25750

Walsh, J. N., O’Brien, M. P., \& Slattery, D. M. (2019). Video Viewing Patterns Using Different Teaching Treatments: A Case Study Using YouTube Analytics. Research in Education and Learning Innovation Archives, 22(22), 78-78. https://doi.org/10.7203/realia.22.15389

Willet, K. B. S. (2019). Revisiting How and Why Educators Use Twitter: Tweet Types and Purposes in \#Edchat. Journal of Research on Technology in Education, 51(3), 273-289. https://doi.org/ 10.1080/15391523.2019.1611507

Wilson, L., \& Wu, Y. W. (2020). Crowdfunding on Patreon by YouTube Sailing Channels. SSRN, 1-32. http://dx.doi.org/10.2139/ssrn.2919840

Witherspoon, E. B., \& Schunn, C. D. (2020). Locating and understanding the largest gender differences in pathways to science degrees. Science Education, 104(2), 144-163. https://doi.org/ $10.1002 /$ sce. 21557

Wucherer, B. V., \& Reiterer, S. M. (2018). Language Is a Girlie Thing, Isn't It? A Psycholinguistic Exploration of the L2 Gender Gap. International Journal of Bilingual Education and Bilingualism, 21(1), 118-134. https://doi.org/10.1080/13670050.2016.1142499

Yong, S. T. (2017). Digital Native Students: Gender Differences in Mathematics and Gaming. International Journal of Virtual and Personal Learning Environments (IJVPLE), 7(2), 13-26. http://doi.org/10.4018/IJVPLE.2017070102 